\title{
ARUS MULTIKULTURAL DI INDONESIA DALAM PERSPEKTIF PANCASILA, ISLAM, DAN KEBANGSAAN
}

\author{
Arrum Kharisma' ${ }^{1}$ Nawal El Zuhby², Juliastuti Purwanti ${ }^{3}$, Deta Widyaningrum4, \\ Aisyah Nur An-nisa5, Arif Rahman' \\ 1,2,3,4,5,6Universitas Ahmad Dahlan Yogyakarta; Indonesia \\ Email; nawal1900031016@webmail.uad.ac.id
}

\begin{abstract}
Multiculturalism is an understanding of the diversity of culture and in this diversity is born a related understanding of equality, justice, peace, tolerance, and others. Multiculturalism in Pancasila uses the concept of gotong royong which allows all aspects of the Indonesian homeland to be recognized. In Islam, Allah SWT has explained, among others, in QS Al-Hujurat: 13 and QS Hud: 118-119 there is diversity between humans on earth. Multiculturalism in nationality according to historical records, the Indonesian nation has had diversity since the century before independence and has become a proud unity. This journal aims to analyze the currents of multiculturalism in Indonesia from the perspective of Pancasila, Islam, and nationality. This research method uses qualitative research methods using a library research approach. The main data sources in this research are multicultural currents in the perspective of Pancasila, Islamic nationality, and research articles that are relevant to this research. Collecting data in this study through a search of scientific literature related to the theme of this research. The results of this research conclude that multicultural implementation in the perspective of Pancasila, Islam, and nationality can be by building a harmonious relationship through multicultural teaching exercises, especially instructive exercises to grow insight and get attention, mentality, and behavior towards strict regional diversity, social and local. Religion and Pancasila have a strong relationship so that there is never a conflict between the two.
\end{abstract}

Keywords; Islam; Multicultural; Nationality; Pancasila.

\section{PENDAHULUAN}

Indonesia adalah negara yang sangat beragam. Indonesia memiliki banyak sekali perbedaan, baik dalam hal agama, ras, kebangsaan, budaya, maupun bahasa. Kontras-kontras dalam bahasa, adat, budaya, kualitas bersama, bahkan agama dan keyakinan, tergabung dalam kehidupan yang ketat dan terlalu sulit untuk dianggap terisolasi. Unsur multikultural dalam budaya Indonesia ini kemudian dituangkan dalam kesepakatan politik yang disebut Pancasila, penegasan kepribadian multikulturalisme dalam berbangsa dan bernegara. Multikulturalisme dalam suatu bangsa yang bergantung pada Pancasila, cara hidup budaya masa kini menurut sudut pandang yang dapat diverifikasi di arena publik, berbangsa, dan bernegara bergantung pada Pancasila sebagai premis bernegara dan cara berpikir hidup negara, sehingga dalam ketahanan berbangsa dan bernegara, kualitas multikultural menjadi acuan yang signifikan agar tidak terjadi kontak kepentingan di mata publik. Keragaman ras, suku, bahasa, dan agama merupakan ciri khas serta kelebihan dari bangsa Indonesia yang membedakannya dengan bangsa lain. Namun, perbedaan yang tidak dikelola dengan baik akan menimbulkan konflik dan perselisihan. Oleh karena itu, harus ada formula untuk mendamaikan dan menyatukannya. (Mubit, 2016) Oleh karenanya perlu ada tindakan preventif untuk meredam segala potensi konflik dan membangun sikap kebersamaan, saling menghargai, dan saling menghormati. Salah satu upaya 
Scaffolding: Jurnal Pendidikan Islam dan Multikulturalisme Vol. 3, No. 2, Juli-Desember 2021: 109-122

strategis adalah dengan membangun kesadaran pluralis pada generasi muda melalui pendidikan yang berbasis pada multikulturalisme. (Rijal, 2021) Dalam menyikapi perbedaan-perbedaan tersebut, prinsip hidup berbangsa dan bernegara harus selalu dijunjung tinggi, semboyan Bhinneka Tunggal Ika hendaklah selalu terpatri dalam semangat hidup berbangsa, nilai-nilai persatuan dalam Sumpah Pemuda menjadi kekuatan untuk membangun nasionalisme, serta nilai-nilai luhur yang terkandung dalam Pancasila dapat menjadi way oflife bagi bangsa Indonesia dalam kehidupan sehari-hari. Dalam rangka mentransformasikan nilai-nilai Pancasila dan prinsip-prinsip hidup berbangsa dan bernegara tesebut diperlukan perantara atau media agar mencapai hasil yang maksimal. Sedangkan media yang dapat digunakan adalah pendidikan Islam multikultural. Konsep pendidikan Islam multikultural ini menawarkan sebuah format pendidikan yang mengakomodir perbedaan yang nilai-nilainya didasarkan pada nilai-nilai yang terkandung dalam Al-Quran dan Hadis serta berdasarkan pada makna Pancasila sebagai pandangan hidup dalam kehidupan berbangsa dan bernegara. (Inayatul Ulya, 2016) Hal inilah yang kemudian Islam pada saat itu dijadikan sebagai landasan pandangan "manusia yang tersebar luas", dengan demikian akan membangkitkan ketabahan antar manusia. Konsekuensinya, analis perlu untuk membongkar lebih dalam dimensi Pancasila, Islam, dan identitas, untuk melihat bagaimana hubungan yang signifikan antara multikulturalisme di Indonesia dengan Pancasila dan Islam. Rahman menilai, bahwa konsekuensi dari konteks multikultural di Indonesia sendiri membuka beragam pandangan, perbedaan, dan kekhasan, sehingga terdapat peluang kekuatan integrasi di satu sisi dan disintegrasi di sisi yang lain. Hal tersebut bisa terjadi karena dilatarbelakangi perbedaan yang mencolok diberbagai macam aspek. Penting untuk menghadirkan pemahaman tentang diversity (perbedaan) terutama dalam konteks keutuhan bangsa yang diilhami dari ideologi Pancasila yang lekat dengan nilai-nilai keIslaman (Rahman, 2016). Multikulturalisme di Indonesia bersumber pada UUD 1945 yang menyatakan bahwa bangsa dan masyarakat Indonesia terdiri dari beragam kelompok etnis yang memiliki komitmen untuk membangun Indonesia sebagai negara bangsa. Komitmen dan pengakuan tesebut dinyatakan dalam simbol Garuda Pancasila. Simbol ini menyatakan kehidupan kebangsaan itu memerlukan persyaratan yaitu adanya tolerenasi sebagai bentuk penghargaan atas keberadaan kebudayaan masyarakat Indonesia yang beragam ( Bhinneka Tunggal Ika). (Sudharto, 2012) Dalam konteks ini, kesadaran akan multikulturalisme menjadi hal yang sangat penting. Pendidikan memiliki peranan penting dalam membentuk masyarakat terkhusus peserta didik agar memiliki rasa saling menghargai dan memahami. Masyarakat Indonesia yang sangat beragam akan tepat jika dikelola dengan pendekatan multikultural agar interaksi dan integrasi dapat berjalan dengan baik sehingga dapat menumbuhkan sikap kebersamaan, toleransi, humanis, dan demokratis sesuai dengan isi Pancasila. Tulisan ini difokuskan pada pembahasan mengenai arus multikultural di Indonesia dalam perspektif Pancasila, Islam, dan Kebangsaan. Dalam tulisan ini juga dibahas tentang 
Scaffolding: Jurnal Pendidikan Islam dan Multikulturalisme

Vol. 3, No. 2, Juli-Desember 2021: 109-122

pentingnya pendidikan multikultural di Indonesia sebagai salah satu upaya untuk mencegah terjadinya konflik karena keberagaman yang ada di Indonesia.

\section{METODE}

Penelitian ini disusun dengan menggunakan metode kualitatif dan melalui pendekatan library research. Tujuan dilakukan penelitian ini adalah untuk mengetahui arus multikultural di Indonesia. Data yang diperoleh diklasifikasikan berdasarkan tema dan topik-topik utama dari penelitian ini berupa sejauh mana gagasan multikultural di Indonesia jika dilihat dalam perpsektif Pancasila, Islam, dan Kebangsaan. Data tersebut kemudian dianalisis lebih dalam dengan membandingkan data dan fakta di Indonesia dengan mempertimbangkan apakah data literatur dapat terkonfirmasi dan kemudian disajikan dengan pendekatan analisis diskriptif.

\section{HASIL DAN PEMBAHASAN}

\section{Terminologi Multikultural}

Akar kata "multikulturalisme" adalah budaya. Pengertian kebudayaan menurut para ahli sangat beragam, namun dalam konteks ini kebudayaan dilihat dari fungsinya sebagai pedoman hidup manusia. Dalam konteks perspektif, multikulturalisme merupakan ideologi yang dapat menjadi alat atau sarana peningkatan derajat kemanusiaan. Multikulturalisme mengakui dan meyakini perbedaan dalam kesetaraan, baik secara individu maupun budaya. Multikulturalisme memandang masyarakat memiliki budaya yang sama, yang coraknya seperti mozaik. Mozaik mencangkup semua budaya masyarakat lebih kecil yang membentuk masyarakat lebih besar yang memiliki budaya seperti mozaik. Dari beberapa pengertian multikultural, ada pengertian bahwa multikultural yakni kebudayaan. Kata multi berarti banyak, kultur yang berarti budaya dan isme yang berartikan paham atau aliran (Khairuddin, 2018). Will Kimlicka berpendapat bahwa multikulturalisme adalah tentang pengakuan, penghormatan, dan keadilan bagi etnis minoritas, baik dalam hal universal yang terkait dengan hak individu maupun komunitas yang secara kolektif mengekspresikan budaya mereka. Bagaimana ideologi multikulturalisme diserap dalam interaksi yang berbeda yang ada dalam struktur yang berbeda kegiatan manusia termasuk dalam kehidupan-kehidupan sosial, ekonomi dan bisnis, serta kehidupan politik, dan berbagai kegiatan komunitas lainnya. Interaksi ini menyebabkan munculnya pemahaman yang berbeda tentang multikulturalisme. Lebih jauh, perbedaan ini berimplikasi pada perbedaan sikap dan perilaku dalam menghadapi masyarakat multikutural. Sebagai ideologi, multikulturalisme harus diperangi karena diperlukan sebagai dasar bagi tegaknya demokrasi, hak asasi manusia rakyat, dan kesejahteraan rakyatnya (Ibrahim, 2013).

Multikulturalisme sebagai sebuah konsep mengandung makna bahwa setiap orang dilahirkan di dunia dalam keadaan yang unik. Ini juga menyiratkan bahwa fenomena ini adalah 
Scaffolding: Jurnal Pendidikan Islam dan Multikulturalisme Vol. 3, No. 2, Juli-Desember 2021: 109-122

sunnatullah atau hukum Allah, yang tidak hanya berlaku untuk ukuran masyarakat di dunia. Namun, dalam kadar yang lebih sedikit, perbedaan sangat terasa, mulai dari tata bahasa, intonasi, sikap, dan sebagainya. Keberagaman ini diharapkan dapat selalu dipertahankan untuk menciptakan suasana dan kondisi saling menghargai dan menghormati dalam kerangka harmonisasi (Halim, 2021). Menurut Rahmatullah, multikulturalisme dalam Bahasa Arab disebut tasamukh, yang berarti sikap menerima pihak lain dan menghargai perbedaan. Multikulturalisme dalam kehidupan bermasyarakat, berbangsa, dan bernegara memiliki empat makna, yaitu rasa senasib, tercintanya persatuan dan kesatuan, rasa kebangsaan atau nasionalisme, pengakuan dan penghormatan terhadap hak asasi manusia, dan tidak memfitnah budaya, kebangsaan, adat istiadat orang lain (Iryani \& Suriate, 2021). Multikultural memiliki pengertian yang luas. Menurut para pakar, multikulturalisme itu beragam, tetapi dapat dilihat dari konteksnya dalam perspektif budaya, maka multikulturalisme ialah dalam meningkatkan derajat seseorang atau manusia ideologi sebagai alat untuk meningkatkannya. Multikulturalisme adalah paham tentang keragaman-keragaman sebuah budaya dan didalam keragaman ini lahirlah pemahaman yang berkaitan tentang kesetaraan, keadilan, perdamaian, toleransi, dan yang lainnya (Khairiah, 2020).

\section{Pancasila dan Multikulturalisme}

Soekarno turut mewujudkan negara Indonesia yang heterogen dengan menyebarluaskan konsep gotong royong. Konsep gotong royong memungkinkan semua aspek di Indonesia diakui keberadaannya. Pluralisme tumbuh subur karena prinsip gotong royong. Selanjutnya, prinsip gotong-royong memastikan bahwa semua aspek saat ini diperlakukan sama dan berkontribusi untuk Indonesia. Oleh karena itu, tidak salah apabila Indonesia yang memiliki keragaman dalam berbagai aspek menggunakan konsep gotong royong sebagai landasan. Karena ujung gotong royong juga menjadi pemicu tumbuhnya semangat multikultural yang menghargai berbagai keragaman untuk kemajuan bersama. Soekarno menggambarkan "Indonesia untuk Semua," di mana seluruh warga negara merasa seperti orang Indonesia dan bekerja sama untuk mencapai Indonesia yang sama(Asmuri, 2017). Ambisi dan tujuan rakyat untuk negara ini adalah kebersamaan, nasionalisme, keadilan, dan kesejahteraan. Semua kesenjangan sosial terintegrasi dalam Pancasila yang sarat dengan semangat gotong royong. Pancasila memiliki keunggulan sebagai landasan ideal bagi kehidupan berbangsa, bernegara, dan bermasyarakat. Namun, beberapa orang, baik komunis atau agama, tidak puas dengan dia sekarang dan berusaha untuk menggantikannya. Banyak perusahaan telah muncul sepanjang sejarah Indonesia sebagai akibat dari ketidakpuasan ideologis dan keinginan untuk memajukan kelompoknya sendiri di atas kepentingan bangsa dan negara. Terdapat berbagai perdebatan tentang bentuk negara sejak awal, apakah itu dibuat berdasarkan agama atau dalam bentuk negara sekuler. Ada dua kelompok utama yang saling bertentangan, diantaranya gerakan nasionalis dan keagamaan. Konflik dan 
Scaffolding: Jurnal Pendidikan Islam dan Multikulturalisme

Vol. 3, No. 2, Juli-Desember 2021: 109-122

persoalan "rumit" (kompleks) muncul hingga Soekarno berpidato terkait Pancasila menjadi pandangan hidup bangsa (Janah, 2018).

Menurut Soekarno, suara mayoritas akan menghasilkan kesewenang-wenangan dan penindasan terhadap minoritas. Dalam konstruksi sistem demokrasi Indonesia, Soekarno tidak lagi menyetujui pemakaian bahasa mayoritas-minoritas. Kata itu muncul dari pola pikir liberal. Lebih dari itu, satu suara, bahkan dari kelompok minoritas sekalipun, bisa berdampak sama bagi kehidupan bernegara. Sistem gotong royong rakyat Indonesia jelas tidak mengecualikan minoritas; sebaliknya, ia menggabungkan semua orang ke dalam semangat persatuan. Soekarno percaya bahwa ada dua konsep yang tidak dapat dipisahkan yaitu nasionalisme dan internasionalisme (kemanusiaan). Karena ada nasionalisme yang didasarkan pada keyakinan yang bertentangan dengan kemanusiaan. Nasionalisme semacam itu adalah nasionalisme chauvinistik yang ditemukan di Jerman, di mana "Deutsschland über Alles" adalah kepercayaannya. Nasionalisme Indonesia harus maju melampaui kekerabatan, yang dapat menyatukan beragam suku, agama, budaya, bahkan batas-batas negara. Pengertian gotong royong tidak hanya diterapkan oleh masyarakat Indonesia dalam kehidupan sehari-hari, tetapi juga sangat bermanfaat bagi masyarakat internasional (contohnya ketika ada kegiatan membantu korban gempa dan tsunami di Nanggroe Aceh Darussalam). Pancasila dipilih "dari generasi ke generasi" berdasarkan budaya bangsa dan "sebagai perasaan rakyat yang selama ini ada di hati rakyat", menurut Soekarno. Istilah Pancasila dicetuskan oleh Mpu Prapanca dalam Kitab Negarakertagama.

Bhinneka Tunggal Ika dicetuskan oleh Mpu Tantular di Kitab Sutasoma.Ini menunjukkan bahwa Pancasila telah menjadi citra pribadi masyarakat sejak dahulu kala. Pancasila didasarkan pada semangat "gotong royong", bukan Islam, Kristen, Hindu, atau Buddha, ketika menyangkut konflik agama. Namun, ternyata bagi ormas Islam poin ini kurang memuaskan karena tidak menjembatani tujuan umat Islam. Titik terangnya ada, tetapi tidak lepas begitu saja. Untuk mengatasi perselisihan tersebut, Komite Sembilan dibentuk secara ad hoc atau dikenal sebagai "Piagam Jakarta", dirancang pada 22 Juni 1945. Umat Islam mengungkapkan tujuan mereka dengan memasukkan tujuh frasa bermasalah dalam perintah pertama, yang menunjukkan status Islam sebagai agama mayoritas. AA Maramis, seorang anggota Komite Sembilan yang beragama Kristen, diberi 'batu sandungan', akan tetapi dia juga merasa tak berdaya. Ini akan menjadi lebih jelas ketika skenario terungkap dalam minggu-minggu menjelang pidato 18 Agustus (Ibrahim, 2013). Pada sore hari tanggal 17 Agustus, seorang Jenderal Angkatan Darat Jepang mengungkapkan keberatan Kristen terhadap perumusan dasar Komite Sembilan tentang negara. Prinsip pertama Piagam Jakarta, "Ya Tuhan YME dengan beribadah menurut syariat Islam bagi para anggotanya," menimbulkan keprihatinan besar umat Kristiani. Bung Hatta mengadakan pertemuan para pemimpin Islam pada saat itu untuk membahas situasi tersebut. Kontribusi Bung 
Scaffolding: Jurnal Pendidikan Islam dan Multikulturalisme Vol. 3, No. 2, Juli-Desember 2021: 109-122

Hatta untuk kompromi logis dan percakapan sangat besar. Dia menganjurkan universalitas, ultimatitas, dan singularitas kata "Tuhan," yang merupakan konsep transenden di alam semesta, ide yang mencakup semua kelompok agama dan etnis. Juga, umat Islam menyebut istilah "Yang Maha Kuasa" sebagai "tauhid" Islam. Ini bukan tugas yang berat karena Hatta beragama Islam yang saleh yang tidak masalah mengadopsi rumusan kompromi.

Yang "Maha Satu" terkait dengan kompromi filosofis Hatta pada konsep "yang tertinggi". Akhirnya, tidak ada pihak yang keberatan dan menganggap bahwa Penguasa dan Pencipta adalah orang yang sama. Dengan demikian "Yang Mahakuasa" bukan hanya monopoli Islam, tetapi juga agama Kristen, Hindu, dan agama lainnya. Tubuh UUD 1945, khususnya Pasal 29, diubah untuk mencerminkan modifikasi tersebut dengan menghilangkan tujuh kata yang sama. Di sinilah Pancasila memiliki kekuatan menjadi gagasan kehidupan bangsa, kekuatan pencacahan, dan sebagai pelindung umat beragama yang bertentangan. Hal ini berlangsung sebelum Pidato Kenegaraan Presiden Soekarno pada 18 Agustus, mencegah negara yang baru terbentuk itu untuk segera bubar. Ini adalah bentuk dari semangat gotong royong yang merupakan sentimen Pancasila. Bahkan dalam situasi genting pun, para founding fathers negara menginternalisasi dan bahkan menjalankan semangat gotong royong dalam mendirikan negara. Oleh karena itu, Indonesia didirikan untuk kemaslahatan seluruh rakyat Indonesia. Dengan kata lain, jangan angkat agama saat membahas tentang Indonesiaan. Sejak awal, semangat gotong royong bangsa ini sudah mendarah daging di hati masyarakat Indonesia. Anehnya, ini disahkan melalui musyawarah untuk membangun konsensus untuk kebaikan yang lebih besar dari komunitas pluralistik. Pengaruh Pancasila terhadap komunis dan bahkan umat beragama tidak dapat disangkal. Namun, 'sumpah' Eka Prasetya Panca Karsa kepada seluruh lapisan masyarakat dan lembaga sosial negara pada masa Orde Baru, yang bersumber dari hasil TAP MPR IV/1978, mengisyaratkan bahwa Pancasila harus kembali memperhatikan kekuatan gaibnya ketika berhadapan dengan agama, khususnya Islam. Bahkan setelah kemampuan supranaturalnya dipaksakan pada satu prinsip untuk semua organisasi sosial-keagamaan, termasuk lembaga keagamaan, seperti gereja.

Langkah ekstrim Orde Baru dalam menegakkan kesaktian Pancasila berhasil pada saat itu. Pelajar SMA ikut serta dalam metode indoktrinasi melalui penataran P4 (Pedoman Mempraktikkan Pancasila). Di sisi lain, T.B. Simatupang merasa bahwa teknik indoktrinasi ini diperlukan, meskipun hanya dalam konteks menghadapi resiko komunis. Ketika Orde Baru tumbang dan semangat reformasi memberontak, 'keajaiban' seperti itu pun memudar. Bahkan kini masih ada pandangan sektarian yang terkesan alergi terhadap Pancasila. Pancasila seolaholah telah diremukkan, dan dia tidak lagi dihormati. Umat beragama tertentu saat ini masih bercita-cita untuk tujuan kuno mendirikan negara Islam, bahkan jika itu tidak lagi dapat ditoleransi. Beberapa organisasi nasionalis, terutama Kristen, percaya bahwa Pancasila perlu 
Scaffolding: Jurnal Pendidikan Islam dan Multikulturalisme Vol. 3, No. 2, Juli-Desember 2021: 109-122

dihidupkan kembali sebagai filsafat hidup bangsa dan negara sebelumnya atau Welstanchauung. Itu tidak berhenti di situ, harus dilakukan setiap hari di tingkat masyarakat untuk menghapus ekses-ekses reformasi saat ini (yang dilakukan atas nama agama oleh segelintir "petualang" politik-sosial-komunitas yang ingin meninggalkan sejarah perjalanan bangsa ini. Bangsa saat ini terbelah di antara dua kutub, yaitu "peremajaan Pancasila" dan "penggantian Pancasila dengan syariah". Jika yang terakhir ini benar, bangsa ini akan mulai hancur. Meskipun para leluhur kita dengan sengaja dan sungguh-sungguh ingin bekerja sama membangun negeri ini dari nol, namun upaya sekelompok kecil orang yang membentuk organisasinya sendiri pada masa reformasi ternyata menyimpan dendam sejarah yang masih membara. Saat ini, menurut Hatta, semua pihak harus sepaham dengan para pendiri dalam mendorong semangat gotong royong. Nilai-nilai Islam Hatta selalu diresapi dengan keindonesiaan yang kuat, tanpa perlu definisi "arabisasi" yang formal dan berlebihan (seperti yang terjadi pada zaman sekarang). Dimulai dengan pembentukan peraturan daerah dan peraturan/perundang-undangan lainnya dengan kehalusan syariah, indikasinya sudah terlihat. Setelah itu, seolah-olah ada "negara di dalam negara, yang dilihat oleh para intelektual sebagai" langkah lain menuju kemerdekaan. Penting untuk mempertimbangkan kembali pertanyaan berikut: "Apakah benar menerapkan hukum Islam di Aceh?" Legislator harus memahami bahwa kekhususan yang mereka ciptakan tetap harus menghormati Pancasila sebagai ideologi bangsa.

Meski secara teknis masih digantung di dinding atau dipajang di mimbar pemerintah daerah, ada risiko Garuda Pancasila akan terabaikan dalam setting 'istimewa' ini. Dalam negara berdaulat, di mana disebutkan bahwa dasar negara dapat diganti dengan 'bermain-main', ini adalah sebuah ironi (walaupun inkonstitusional, tetapi dilegalkan). Keberhasilan bangsa dan seluruh rakyat Indonesia harus didasarkan pada pemahaman Pancasila dan deklarasi Soekarno tentang "negara gotong royong". Yang terjadi justru dianggap sebagai kemenangan kaum nasionalis yang selama ini dituding hanya sekuler. Sebaliknya, kaum Muslimin merasa kalah, dan dikatakan bahwa ketidakpuasan mereka masih bisa dirasakan hingga saat ini. Memang, kerugian politik bisa meninggalkan dendam lama bagi generasi muda, terutama dalam bentuk 'tujuh kata' Piagam Jakarta. Ketika orang-orang yang berusaha memaksakan aktivitas dengan nama agama semakin menyebarkan pengaruh dan bahkan sampai teror ke seluruh masyarakat, sakit hati yang tidak logis menjadi lebih nyata (Munadlir, 2016).

Konsepsi dari Pancasila nampaknya sangat sarat dan lekat dengan apa yang digagas oleh pemahaman multikuluralisme. Sebagai sebuah paham multikulturalisme mengusung kesamaan visi dengan Pancasila sebagai ideologi bangsa. Sekalipun sebenarnya, konsepsi pendidikan multikultural dipopulerkan dari Barat, namun pada dasarnya konteks di Indonesia sejatinya sudah memiliki landasan Pancasila yang berjalan beriringan dan mengakomodir nilai-nilai pendidikan multikultural (Rahman, 2015). Nilai-nilai multikultural dapat diselami dengan 
Scaffolding: Jurnal Pendidikan Islam dan Multikulturalisme Vol. 3, No. 2, Juli-Desember 2021: 109-122

memaknai ideologi bangsa tersebut yang sudah sejak lama diilhami dalam kehidupan masyarakat, terlebih lagi semua satuan dan tingkat pendidikan di Indonesia mewajibkan dilaksanakannya pendidikan Pancasila. Adanya aturan diwajibkannya pendidikan Pancasila pada kehidupan masyarakat dan lembaga pendidikan diharapkan dapat menciptakan rakyat yang saling menghargai perbedaan antar masyarakat. Sehingga tujuan pendidikan nasional yang berakar pada agama, kebudayaan, serta dapat mengikuti zaman dapat tercapai. Berdasarkan penelitian yang dilakukan oleh (Misnaini, 2018) menunjukkan bahwa setelah dilaksanakannya pendidikan Pancasila terdapat peningkatan yang dialami oleh mahasiswa terhadap nilai-nilai Pancasila. Sebagai warga negara Indonesia yang memiliki keberagaman dan kita diwajibkan untuk mempelajari pendidikan Pancasila maka kita harus dapat mengolah segala sesuatu tentang perbedaan yang ada dikehidupan, apabila kita tidak dapat mengolah hal tersebut maka akan memicu masalah yang dapat memecah belah persatuan dan kesatuan (Shofa, 2016).

\section{Multikultural dalam Perspektif Islam}

Multikulturalisme esensinya adalah memandang perbedaan antar sesama manusia itu sama, tidak ada perbedaan yang membanding-bandingkan manusia, seperti pada bentuk wajah, warna kulit, suku, dan lain-lain. Dalam ajaran Islam, Allah telah menegaskan melalui kalam-Nya dalam hal perbedaan antar manusia di bumi. Terdapat dalam surat Al-Hujurat: 13, dalam Ayat ini Allah telah bersabda bahwasannya Allah menciptakan manusia laki-laki dan perempuan, bersuku-suku dan berbangsa-bangsa agar mereka saling mengenal antar sesama. Dan juga Allah menjelaskan dalam Ayat ini bahwa yang paling mulia disisi Allah itu bukanlah seseorang yang banyak harta, atau berkulit putih, akan tetapi yang paling mulia ialah yang paling bertakwa. Makna bertakwa disini ialah seseorang yang mematuhi segala yang diperintahkan oleh Allah, dan dia menjalankannya, serta menjauhi apa yang Allah larang. Ibnu Katsir menjelaskan bahwa dalam hal kemuliaan, awalnya semua manusia itu sama, baru kemudian mereka dilihat tingkatannya dari segi agama, yaitu ketaatan kepada Allah SWT dan kepada Rasulullah (Muzaki \& Tafsir, 2018).

QS Hud/11: 118-119 dijelaskan juga tentang keberagaman manusia di muka bumi, bahwa manusia diciptakan oleh Allah tidak hanya dengan satu tipe saja, akan tetapi bermacam-macam. Karena Allah mempunyai tujuan dengan penciptaan manusia yang beragam, salah satunya agar mereka tidak selalu berselisih pendapat. Hal ini juga dijelaskan dalam QS Hud/11: 118-119, bahwasannya Allah berfirman yang artinya: "Jikalau Tuhanmu menghendaki, tentu Dia menjadikan manusia umatyang satu, tetapi mereka senantiasa berselisih pendapat,. kecuali orangorang yang diberi rahmat oleh Tuhanmu. dan untuk itulah Allah menciptakan mereka. Kalimat Tuhanmu (keputusan-Nya) telah ditetapkan: sesungguhnya aku akan memenuhi neraka Jahannam dengan jin dan manusia (yang durhaka) semuanya." 
Scaffolding: Jurnal Pendidikan Islam dan Multikulturalisme Vol. 3, No. 2, Juli-Desember 2021: 109-122

Ayat ini menegaskan bahwa ada bermacam-macam manusia, ada yang taat dan ada pula yang durhaka kepada Allah. Allah dapat menciptakan semua orang dengan tipe yang sama dan mereka semua percaya pada kebenaran atau beriman kepada Allah. Akan tetapi iman seperti itu tidak ada gunanya jika mereka selalu berselisih pendapat. Dahulu umat manusia adalah umat yang satu saat nabi adam dan hawa diturunkan, kemudian transformasi umat ini menjadi umat yang banyak berimplikasi pada multikultural syari at para rasul dengan banyak dan beragamnya risalah agama (Roswati, 2019). Multikultural dari segi budaya dan juga agama adalah fakta yang tidak dapat di tolak dari zaman dahulu hingga sekarang (Suparman, 2017). Perbedaan yang ada saat ini telah digambarkan dalam Al-Qur`an dan hadist nabi seperti yang sudah dijelaskan sebelumnya. Akan tetapi banyak dari umat muslim yang belum mengerti sepenuhnya tentang hal ini, maka dari itu sebagai seorang muslim yang taat kepada Allah, semestinya kita mengetahui aturan dan hak-hak kepada sesama yang telah termaktub di dalam kitab suci. Saling menghargai satu sama lain dalam Islam sangat ditekankan, karena itu termasuk salah satu dari akhlak terpuji bagi seseorang, seperti halnya dalam kasus multikultural di Indonesia, beragam suku, bangsa, budaya yang ada bukan menjadikan setiap diri merasa saling berbangga diri, justru dari situlah setiap manusia bisa saling mengenal dan menghargai satu sama lain.

\section{Multikultural dalam Perspektif Kebangsaan}

Menurut catatan sejarah, keragaman bangsa Indonesia sudah ada semenjak berabadabad sebelum kemerdekaan dan telah menjadi satu kesatuan yang membanggakan. kebesaran Indonesia saat itu tercermin pada Kerajaan Sriwijaya di Sumatera, Kerajaan Elllangga di Jawa Timur, Kerajaan Majapahit dan beberapa kerajaan di Jawa Timur dan Kalimantan, pada saat itu kerajaan-kerajaan ini semuanya menganjurkan keragamaan, terkenal di luar negeri, dan menjalin hubungan kerja sama atas kemitraan yang setara terkenal akan kekayaan alamnya, keragaman budayanya yang mempesona, keramahan serta kesopanan sosial, solidaritas, dan gotong royong. Demikian pula sejak proklamasi kemerdekaan tahun 1945, mereka ikut serta dalam pemeliharaan ketertiban dunia. Kondisi-kondisi ini perlu dipertahankan keberlanjutan dan interitas sebagai kebutuhan penting hidup dalam mata pencaharain 223 juta warga. Namun, perjalanan berikutnya sebagai akibat derasnya arus informasi dan pesatnya kemajuan ilmu pengetahuan dan teknologi, globalisasi, pergerakan imigrasi/penduduk internasional, nasional dan lokal, komunikasi, transportasi dan pariwisata, serta perdagagangan internasional dan regional, integritas dan identitas nasional yang awalnya meningkat kini terjadi kekacauan dan perpecahan. Perubahan mengancam keberadaan negara membahayakan keutahan NKRI saat ini, pada gilirannya, bukan tidak mungkin untuk meniadakan NKRI pada peta Indonesia dari negaranegara di dunia. Seminar bertema "integrasi multikultural dan etnis" harus menjadi forum refleksi dan pemikiran pertimbangkan untuk memobilisasi gerakan nasional yang bersatu dan 
kuat. Hal tersebut menjaga harkat dan martabat Negara Kesatuan Republik Indonesia untuk memahami dan menghayati ideologi multikultural (Sudharto, 2012).

Kesadaran tentang multikulturalisme saat ini menjadi suatu kebutuhan sangat penting bagi manusia masyarakat di Indonesia agar dapat menghadapi tantangan global di masa yang akan mendatang. Pendidikan multikulturalisme bagi bangsa Indonesia bisa dijadikan sebagai wahana menyiapkan negara Indonesia untuk menghadapi arus budaya luar di era globalisasi serta menyatukan kewarganegaraan itu sendiri yang terdiri dari berbagai macam budaya atas dasar nilai-nilai kebangsaan (core values) jati-diri bangsa. Multikulturalisme ialah suatu ideologi serta sebuah alat agar meningkatkan derajat manusia dan kemanusiaannya. Mengingat pentingnya pemahaman mengenai multikulturalisme dalam membangun kehidupan dalam berbangsa dan bernegara, maka pendidikan multikulturalisme ini perlu dikembangkan sebagai program berkelanjutan. Melalui pendidikan multikulturalisme ini diharapkan akan dicapai suatu kehidupan masyarakat yang damai, harmonis, menjunjung tinggi nilai-nilai kemanusiaan serta kebangsaan sebagaimana yang telah di tetapkan di dalam Undang-Undang Dasar (Primawati, 2013).

Banyak peneliti percaya bahwa Indonesia adalah tempat peleburan juga merupakan supermarket yang ramai untuk pengaruh juga merupakan agama-agama dunia. Pengganti lainnya tetapi dalam arti tertentu ada juga mode gabungan antara agama-agama eksternal dan tradisitradisi keagamaan lokal. Dari catatan sejarah, pola hubungan antar agama di masa lalu, sangat dipengaruhi oleh politik agama pemerintah kolonial. Masing-masing pihak mempertahankan hubungan, oposisi, persaingan dan ketegangan. Ketidaktahuan sengaja di sulut demi kepentingan politik kolonial, pemerintah kolonial politik agama hanya berdasarkan dogma bukan soal moralita (Hanafy, 2015).

\section{Arus Multikultural di Indonesia dalam Perspektif Pancasila, Islam, dan Kebangsaan}

Kontras seharusnya menjadi dorongan untuk memahami keanggunan Tuhan yang begitu tulus untuk secara konsisten menenun kesesuaian dan perlawanan. Dengan demikian, kontras dan variasi tidak dapat dihindari. Selain itu, dalam perbedaan dan keragaman ini ada kelebihannya, yaitu pertemuan yang berbeda dapat saling melengkapi. Mayoritas budaya Indonesia sendiri pada hakikatnya dapat dilihat sebagai realitas dari sisi yang berbeda. Pihak utama, mayoritas marga, agama dan masyarakat serta bawahannya. Sisi selanjutnya, ke dalam mayoritas kebangsaan, agama dan budaya itu sendiri (Khayati, 2018). Meskipun demikian, seiring dengan perkembangan zaman dan kemajuan mekanis akibat derasnya arus globalisasi, manusia Indonesia menghadapi berbagai macam, salah satunya adalah disintegrasi nilai-nilai Pancasila dalam kehidupan. Filosofi yang berbeda tampak tidak sesuai dan diharapkan dapat menggulingkan Pancasila. Demikian pula, pengembangan filsafat oleh komponen-komponen 
Scaffolding: Jurnal Pendidikan Islam dan Multikulturalisme Vol. 3, No. 2, Juli-Desember 2021: 109-122

tertentu yang tidak bertanggung jawab untuk menggunakan agama tertentu ingin menggantikan sistem kepercayaan Pancasila dan mengubah negara Indonesia menjadi filsafat dan negara yang ketat. Hal ini sebagai perbedaan yang mencolok terhadap gagasan pendirian negara Indonesia, yang tidak didasarkan pada pemerataan yang ketat tetapi berdasarkan pemerataan nasib dan usaha. Jumlah media yang begitu besar berdampak pada kecanggihan negara untuk menjadi tawanan industri dunia maya yang menganggapnya pendek, berpikiran waras, mengabaikan hasilnya. Individu lebih tertarik dan senang dengan masyarakat yang tidak dikenal. Banyak anak kecil yang berpacaran, bergantung pada game internet, perkelahian remaja, pornografi, perlawanan dan lain-lain. Selain itu, banyak anak-anak yang tidak mengingat Pancasila, sakti, lagu-lagu daerah dan umum dan hal-hal lain yang terkait dengan etnis, namun tetap mempertahankan konten media berbasis web yang tidak signifikan (Yani \& Dewi, 2021).

Islam itu moderat, adil dan jalan tengah. Standar ini seharusnya menjadi landasan umat Islam dalam membangun suatu tuntutan hidup yang serasi, baik yang menyangkut intra-ketat maupun antar-ketat, umum atau sedunia. Dengan begitu, umat Islam sebagai bagian terbesar bangsa ini akan menjadi individu yang dapat memberikan harapan pengenalan kehidupan seharihari yang menitikberatkan pada kerukunan. Perbedaan yang ada saat ini telah digambarkan dalam Al-Qur`an dan hadist nabi seperti yang sudah dijelaskan sebelumnya. Akan tetapi banyak dari umat muslim yang belum mengerti sepenuhnya tentang hal ini, maka dari itu sebagai seorang muslim yang taat kepada Allah, semestinya kita mengetahui aturan dan hak-hak kepada sesame yang telah termaktub di dalam kitab suci. Saling menghargai satu sama lain dalam Islam sangat ditekankan, karena itu termasuk salah satu dari akhlak terpuji bagi seseorang, seperti halnya dalam kasus multikultural di Indonesia, beragam suku, bangsa, budaya yang ada bukan menjadikan setiap diri merasa saling berbangga diri, justru dari situlah setiap manusia bisa saling mengenal dan menghargai satu sama lain.

Islam adalah agama yang mengutamakan keuntungan dan menjauhkan dari kerugian. Salah satu upaya untuk membuat hubungan yang serasi adalah melalui latihan pengajaran multikultural, khususnya latihan instruktif untuk menumbuhkan wawasan mendapatkan, perhatian, mentalitas, dan perilaku terhadap keragaman daerah yang ketat, sosial dan lokal. Dengan pengaturan itu, pelatihan multikultural dapat memasukkan pengajaran yang ketat dan sekolah umum yang "Indonesia" karena menerima peluang dan kesulitan dari mayoritas agama, masyarakat, dan budaya Indonesia. Agama dan Pancasila nyambung saling berkaitan, tidak pernah ada pertentangan di antara keduanya. Agama adalah gaya hidup bagi para pengikutnya, dan Pancasila adalah gaya hidup bagi individu Indonesia yang juga individu yang ketat. Pancasila, dalam banyak hal, dapat menjadi titik temu bagi semua keragaman sosial dan etnis yang ketat, dan menggabungkannya ke dalam keragaman sosial tanpa menampilkan satu komponen dan melumpuhkan komponen yang berbeda. Kita dapat menduga bahwa sifat-sifat yang terkandung 
Scaffolding: Jurnal Pendidikan Islam dan Multikulturalisme Vol. 3, No. 2, Juli-Desember 2021: 109-122

dalam Pancasila adalah bawahan dari sifat- sifat yang kaku. Islam, Multikulturalisme, Pancasila, dan Identitas tampak sebagai empat himpunan yang terus hidup memberi warna pada Indonesia selama ini dengan menjaga kualitas konservatifnya, mengikuti dan benar-benar fokus pada kebenaran multikultural kerabatnya, memberi kebebasan politik yang setara dengan siapa pun yang tidak terlalu memikirkan dasar etnis, agama, atau kebangsaan (Alim, 2019).

\section{KESIMPULAN}

Multikulturalisme ialah budaya atau kebudayaan. Dapat diartikan bahwa multikulturalisme tergabung dari kata multi yang memiliki arti banyak, kultur yang memiki arti budaya serta isme yang memiki arti aliran atau paham. Adapun pengertian yang lainnya bahwa multikulturalisme ialah suatu budaya yang mana pada Bahasa Arab disebut sebagai tasamukh yang berarti menerima pihak lain atau menghargai suatu perbedaan. Pluralisme akan tumbuh dengan adanya gotong royong, gotong royong ini akan menjadi pemicu bagi lahirnya multikulturalisme di Negara kita. Keinginan serta tujuan dari masyarakat ini ialah untuk nasionalisme, kebersamaan, kesejahteraan serta keadilan. Maka di sini Pancasila sebagai landasan ideal bagi kehidupan berbangsa dan bernegara. Semua dari kesenjangan sosial terintegrasi kedalam Pancasila yang semangat dengan bergotong royong. Pada multikulturalisme dalam prespektif Islam, menyatakan bahwa setiap manusia, setiap umat harus saling menghargai satu dengan yang lainnya, dengan tidak memandang perbedaan warna kulit, ras, suku, budaya, bangsa antar sesama manusia. Kesadaran tentang adanya multikulturalisme ini adalah salah satu kebutuhan yang terpenting bagi masyarakat Indonesia dimasa sekarang atau dimasa yang akan datang. Pendidikan multikuturalisme jika diterapkan maka akan menjadi suatu yang lebih baik untuk menghadapai arus budaya pada era globalisasi, serta dapat mempersatukan warga Negara itu sendiri. Mengingat bahwa pendidikan multikuturalisme ini sangat penting, maka dengan pendidikan multikulturalisme ini harus dikembangkan sebagai program yang kedepannya akan terus dilaksanakan.

\section{BIBLIOGRAFI}

Alim, S. (2019). Islam, Multikulturalisme, dan Pancasila. 23(2), 85-99.

Asmuri, A. (2017). PENDIDIKAN MULTIKULTURAL (Telaah Terhadap Sistem Pendidikan Nasional dan Pendidikan Agama Islam). POTENSIA: Jurnal Kependidikan Islam, 2(1), 25. https://doi.org/10.24014/potensia.v2i1.2530

Halim, abdul. (2021). Pendidikan Islam Multikultural dalam Prespektif Azyumardi Azra. Fikrotuna, 13(01).

Hanafy, M. S. (2015). Pendidikan multikultural dan dinamika ruang kebebasan. Diskursus Islam, $3(1), 127$. 
Scaffolding: Jurnal Pendidikan Islam dan Multikulturalisme

Vol. 3, No. 2, Juli-Desember 2021: 109-122

Ibrahim, R. (2013). PENDIDIKAN MULTIKULTURAL : Pengertian, Prinsip , dan Relevansinya dengan Tujuan Pendidikan Islam. ADDIN, 7(1), 129-154.

Iryani, I., \& Suriate, M. (2021). Bimbingan Kelompok dengan Teknik Sinema Edukasi Untuk Meningkatkan Kesadaran Multikultural Siswa Kelas XI Di SMA Isen Mulang Palangka Raya. Jurnal Bimbingan Dan KonselingPandohop, Volume I,

Janah, S. N. (2018). Komplek Perumahan Citraland Kecamatan Sambikerep Surabaya Skripsi : Skripsi.

Khairiah. (2020). Multikultural dalam Pendidikan Islam (Sirajuddin (ed.); 1st ed.).

Khairuddin, A., \& Si, M. (2018). IJTIMAIYAH Vol.2 No.1 Januari-Juni 2018 ISSN 2541-660X. 2(1).

Khayati, S. Q. (2018). IDEOLOGI KH. ABDURRAHMAN WAHID DAN BANGUNAN PENDIDIKAN MULTIKULTURAL PASCA TRAGEDI KEBANGSAAN. Tarbiyatuna: Jurnal Pendidikan Islam, 11, 96-127.

Misnaini, S. (2018). PENGARUH PEMBELAJARAN NILAI-NILAI PANCASILA TERHADAP PRILAKU MAHASISWA DI STIK BINA HUSADA. Ilmiah P2M STKIP Siliwangi, 5(2), 75-84.

Munadlir, A. (2016). Strategi Sekolah Dalam Pendidikan Multikultural. Jurnal Pendidikan Sekolah Dasar, Vol. 2, N0, 114-130.

Muzaki, I. A., \& Tafsir, A. (2018). Pendidikan Multikultural dalam Perspektif Islamic Worldview. Jurnal Penelitian Pendidikan Islam, 6(1), 57. https://doi.org/10.36667/jppi.v6i1.154

Primawati, L. (2013). PEMBELAJARAN MULTIKULTURAL MELALUI PENDIDIKAN MULTIKULTURAL BERBASIS NILAI KEBANGSAAN. JUPIIS, 5, 82-92.

Rahman, A. (2015). PARADIGMA KRITIS PANCASILA DALAM DIMENSI PENDIDIKAN ISLAM. Edukasia, 10(01), 125-143. https://doi.org/http://dx.doi.org/10.21043/edukasia.v10i1.788

Rahman, A. (2016). Multikulturalisme Pesantren; Menggagas Pendidikan Islam Pesantren Anti Radikal. Komojoyo Press.

Roswati, N. (2019). Multikulturalisme Dalam Tinjauan Al-Qur'an. Al-Asas, III(2), 1-23.

Shofa, A. M. A. (2016). MEMAKNAI KEMBALI MULTIKULTURALISME INDONESIA DALAM BINGKAI PANCASILA. Jurnal Pancasila Dan Kewarganegaraan, 1(1), 34-41.

Sudharto. (2012). Multikulturalisme dalam Pespektif Empat Pilar Kebangsaan. Jurnal Ilmiah CIVIS, II(1), 121-142.

Suparman, H. (2017). Multikultural dalam Perspektif Alquran. AL QUDS : Jurnal Studi Alquran Dan Hadis, 1(2), 185. https://doi.org/10.29240/alquds.v1i2.250

Yani, D., \& Dewi, D. A. (2021). Aktualisasi Nilai-Nilai Pancasila dan Tantangan di Arus Globalisasi. Jurnal Pendidikan Tambusai, 5(2016), 952-961.

Inayatul Ulya, A. A. ( 2016). Pendidikan Islam Multikultural Sebagai Resolusi Konflik Agama di Indonesia. Fikrah: Jurnal Ilmu Aqidah dan Studi Keagamaan Volume 4 Nomor 1, 21-23. 
Scaffolding: Jurnal Pendidikan Islam dan Multikulturalisme

Vol. 3, No. 2, Juli-Desember 2021: 109-122

Mubit, R. (2016). PERAN AGAMA DALAM MULTIKULTURALISME MASYARAKAT INDONESIA. Epistemé, Vol. 11, No. 1, 164-182.

Rijal, S. (2021). PENDIDIKAN MULTIKULTURAL DALAM PENDIDIKAN ISLAMDAN URGENSINYA DI INDONESIA. AHSANA MEDIAJurnal Pemikiran, Pendidikan dan Penelitian Ke-Islaman Vol. 7, No.1 , 73-74.

Sudharto. (2012). Multikulturalisme Dalam Perspektif Empat Pilar Kebangsaan. Jurnal Ilmiah CIVIS, Volume II, No 1, 130-135. 